\title{
Mannequin-based simulation as an educational tool for learning injection techniques: medical students' view points
}

\author{
Lavanya S. H.*, Kalpana L.
}

Department of Pharmacology, BGS Global Institute of Medical Sciences, Bangalore, Karnataka, India

Received: 03 February 2018 Accepted: 06 March 2018

\section{*Correspondence to:}

Dr. Lavanya S. H.,

Email: lavanyasumanthraj@ gmail.com

Copyright: (C) the author(s), publisher and licensee Medip Academy. This is an openaccess article distributed under the terms of the Creative Commons Attribution NonCommercial License, which permits unrestricted noncommercial use, distribution, and reproduction in any medium, provided the original work is properly cited.

\begin{abstract}
Background: Mannequin-based training devices are simulation adjuncts that mimic reality in healthcare settings for acquiring basic procedural skills, without compromising patient safety. The current study aims to explore students' perceptions of mannequin-based simulation as an educational tool and perceived changes in self-confidence by using a mixed-method research.

Methods: This questionnaire-based study was conducted in 2nd year MBBS students. Pre-validated questionnaires measured the quantitative and qualitative aspects of simulation-training in-terms of their relevance as teaching-learning tool, perceived benefits of sessions, and their importance for future use. The study further attempted to note any perceived change in students' confidence, measured before and after sessions. Chi-square and Fischer-exact test were computed for quantitative responses. Wilcoxon signed-rank test (two-tailed) was used to analyse students' confidence rating before and after simulation. Categorical data were represented as frequencies and proportions.

Results: Overall, the sessions were well received by students. Over $90 \%$ of students agreed that simulation is a safe, enjoyable and feasible modality for acquiring basic clinical skills. Majority opined that sessions helped them integrate basic-life sciences and clinical concepts, improved attention span and urged inclusion in undergraduate curriculum. Students perceived significant improvements $(\mathrm{p}<0.001)$ in confidence post-training. Free-text responses were positive with students highlighting the need for simulation sessions and suggestions for improvement.

Conclusions: Most students consider mannequin-based learning as an essential tool to acquire procedural skills. By promoting active student engagement and impactful learning, simulations justify inclusion in medical curriculum for better patient safety.
\end{abstract}

Keywords: Mannequins, Medical, Pharmacology, Perceptions, Simulation

\section{INTRODUCTION}

Acquiring basic procedural skills is one of the competencies required of a medical graduate for ensuring patient safety. ${ }^{1}$ Traditionally, students have learnt this art and science by observing their experienced counterparts at the bedside, followed by independent execution of skills on real human patients. ${ }^{2}$ However, in the pursuit of achieving these skills, patients' safety may be compromised as they may inadvertently be exposed to the hazards of medication errors. Some of these concerns may be addressed by Simulation-based Medical education. ${ }^{3}$

"Simulation is a training and feedback method in which learners practice tasks and processes in life-like circumstances using different technologies, such as models or virtual reality, with feedback from observers, peers, actor-patients, and video cameras to assist 
improvement in skills". ${ }^{4}$ Although the aviation, aerospace and nuclear industries are considered the pioneers in simulation-based training, this method has made significant in-roads into medical education, with their wide spread usage in emergency care, anaesthesia and other clinical settings. ${ }^{3}$ Adopting these techniques in standardized clinical training enables creation of a safe environment where students have the advantage of repeated learning and re-training with no fear of causing patient harm. ${ }^{5}$

Numerous studies have added to the growing evidence regarding simulation's effectiveness, thus validating its inclusion in health professionals' education. ${ }^{4-8}$ However, in most of these studies, specific components of simulation-based training have been the areas of interest, without much emphasis given to understanding the subtle nuances of learner's perceptions of simulation. Understanding the learner's perspective to see if it matches with that of the educator is of paramount significance to reduce the critical gap of teaching and learning, thus maximizing the utility of simulation-based education. ${ }^{9}$ Hence the present study was aimed to gain a rich understanding of students' perceptions regarding benefits, challenges, effectiveness in instilling confidence and the realism of simulation experience in learning injection techniques using mannequin-based simulation by using a mixed method research.

\section{METHODS}

\section{Study setting}

Authors present a mixed-method research that was conducted in ninety-nine, $2^{\text {nd }}$ year undergraduate medical students attending pharmacology classes during the academic year 2015-16. This study aimed to explore the perceptions, based on the experiences of medical students who attended the mannequin-based simulation exercises for learning injection administering techniques, during regular pharmacology practical sessions using a selfadministered questionnaire. Further, the study attempted to note any perceived change in students' confidence, measured between two time points, before and after simulation sessions. Students' preferences for the entire exercise was further analysed by using a free-text response written survey.

\section{Training tools}

Mannequins are task-specific simulators that can range in their levels of realism from low-fidelity to high-fidelity. ${ }^{4}$ Part-task trainers are a type of segmented clinical task trainers that represent selected anatomical areas of the human body, such as an IV arm. An injectable training arm model (XC-434) and buttock injection simulator (XC431A) were the simulation models used in this study for intravenous (IV) injection and intramuscular (IM) injection respectively.
Ethical clearance was obtained from the Institutional Ethics Committee. The students were briefed about the objectives of the study and a written informed consent was taken for their participation. A manual containing specific instructions on injection techniques, questionnaires and student confidence rating scales required for the study were prepared and subjected to peer-review within the institution. Following theoretical instructions on the techniques of IV and IM injections, students were invited to rate their confidence in administering injections in clinical settings on a Likert scale of 1-5 (1=Not confident at all; 5=extremely confident) for various parameters (Figure1). This was followed by practical sessions. The students worked in small groups of eight to ten. The injection techniques were demonstrated on mannequins by faculty, followed by practice sessions with students working in teams.

Outcomes' Assessment: At the end of practice sessions, students who attended both IV and IM training sessions were handed over a pre-validated questionnaire which included the students' perspectives on:

- Satisfaction and preference for mannequin-based simulation - Answered on a 5-point Likert scale with the categories "Strongly disagree" - (score 1) to "Strongly Agree" - (score 5)

- Confidence rating after simulation - Measured on a 5point Likert scale; "Not confident at all - (Score 1) to "Extremely confident"- (Score 5)

- A free-text response survey - Included four variables to record the students' thoughts on simulation-based learning in depth namely "The most helpful aspect of session", "The least helpful aspect", "Things you want to change about the session" and "Do you see the need for such sessions and why?"

All the questionnaires were anonymous, marked only with a number to match the pre and post session confidence rating.

\section{Statistical analysis}

Data was entered into Microsoft excel data sheet and analyzed using standard statistical package. The responses were then divided into "Accept" category (strongly agree and agree) and "Reject"category (strongly disagree and disagree) and neutral was considered as separate. Chisquare test and Fischer exact test (cell frequency $<5$ ) were then computed for statistical significance. Wilcoxon signed-rank test (two-tailed) was applied to analyse students' confidence rating before and after simulation. Categorical data were represented as frequencies and proportions. $\mathrm{P}$ value of $<0.05$ was considered statistically significant.

\section{RESULTS}

Out of the ninety-nine students who attended the pharmacology practical sessions, a total of 84 students 
$(84.8 \%)$ returned the questionnaires. Of these $59.6 \%$ $(n=59)$ were females and $40.4 \%(n=40)$ were males. The following are the findings of the study.

\section{Satisfaction and preference for mannequin-based simulation}

Over ninety percent of students agreed completely/ in-part that simulation exercises provided a safe environment to acquire basic clinical skills. Majority of the students $(>80 \%)$ were of the opinion that simulation helped them integrate basic life sciences and clinical concepts, improved their attention span and also urged its inclusion in undergraduate curriculum. Around 50\% accepted simulation as an adjuvant to traditional teaching methods (Table 1).

Table 1: Students' satisfaction and preference for mannequin-based simulation in learning injection techniques.

\begin{tabular}{|c|c|c|c|c|c|c|c|c|}
\hline Parameters & $\begin{array}{l}\text { Strongly } \\
\text { agree }\end{array}$ & Agree & Neutral & Disagree & $\begin{array}{l}\text { Strongly } \\
\text { disagree }\end{array}$ & $\begin{array}{l}\text { Mean } \\
\text { score }\end{array}$ & SD & $P$ value \\
\hline $\begin{array}{l}\text { Simulation exercise was a } \\
\text { valuable use of my time }\end{array}$ & $\begin{array}{l}29 \\
(34.5 \%)\end{array}$ & $\begin{array}{l}38 \\
(45.2 \%)\end{array}$ & $\begin{array}{l}14 \\
(16.7 \%)\end{array}$ & $\begin{array}{l}3 \\
(3.6 \%)\end{array}$ & 0 & 4.10 & 0.8 & 0.18 \\
\hline $\begin{array}{l}\text { Simulation can be an adjuvant } \\
\text { to traditional teaching } \\
\text { methods } \dagger\end{array}$ & $\begin{array}{l}7 \\
(8.3 \%)\end{array}$ & $\begin{array}{l}37 \\
(44 \%)\end{array}$ & $\begin{array}{l}29 \\
(34.5 \%)\end{array}$ & $\begin{array}{l}8 \\
(9.5 \%)\end{array}$ & $\begin{array}{l}3 \\
(3.6 \%)\end{array}$ & 3.44 & 0.9 & $0.003^{*}$ \\
\hline $\begin{array}{l}\text { Simulation exercises should } \\
\text { be included in the } \\
\text { undergraduate curriculum }^{¥}\end{array}$ & $\begin{array}{l}21 \\
(25 \%)\end{array}$ & $\begin{array}{l}52 \\
(61.9 \%)\end{array}$ & $\begin{array}{l}10 \\
(11.9 \%)\end{array}$ & $\begin{array}{l}1 \\
(1.2 \%)\end{array}$ & 0 & 4.10 & 0.64 & $0.009 *$ \\
\hline $\begin{array}{l}\text { Increased my attention span as } \\
\text { I was actively participating }\end{array}$ & $\begin{array}{l}30 \\
(35.7 \%)\end{array}$ & $\begin{array}{l}41 \\
(48.8 \%)\end{array}$ & $\begin{array}{l}11 \\
(13.1 \%)\end{array}$ & $\begin{array}{l}2 \\
(2.4 \%)\end{array}$ & 0 & 4.17 & 0.74 & $0.04 *$ \\
\hline $\begin{array}{l}\text { Helped me to integrate the } \\
\text { concepts of basic sciences and } \\
\text { clinical problem solving }\end{array}$ & $\begin{array}{l}29 \\
(34.5 \%)\end{array}$ & $\begin{array}{l}44 \\
(52.4 \%)\end{array}$ & $\begin{array}{l}10 \\
(11.9 \%)\end{array}$ & $\begin{array}{l}1 \\
(1.2 \%)\end{array}$ & 0 & 4.20 & 0.69 & $0.009 *$ \\
\hline $\begin{array}{l}\text { Provided a safe environment } \\
\text { to practice basic clinical } \\
\text { procedural skills }\end{array}$ & $\begin{array}{l}37 \\
(44 \%)\end{array}$ & $\begin{array}{l}42 \\
(50 \%)\end{array}$ & $\begin{array}{l}4 \\
(4.8 \%)\end{array}$ & $1(1.2 \%)$ & 0 & 4.42 & 0.64 & $0.005^{*}$ \\
\hline $\begin{array}{l}\text { Repeated practice with } \\
\text { mannequins might help } \\
\text { improve patient safety }\end{array}$ & $\begin{array}{l}43 \\
(51.2 \%)\end{array}$ & $\begin{array}{l}29 \\
(34.5 \%)\end{array}$ & $\begin{array}{l}12 \\
(14.3 \%)\end{array}$ & 0 & 0 & 4.36 & 0.72 & 0.26 \\
\hline
\end{tabular}

$\dagger$ Chi square test ${ }^{¥}$ Fisher exact statistics $* \mathrm{P}<0.05$ considered statistically significant

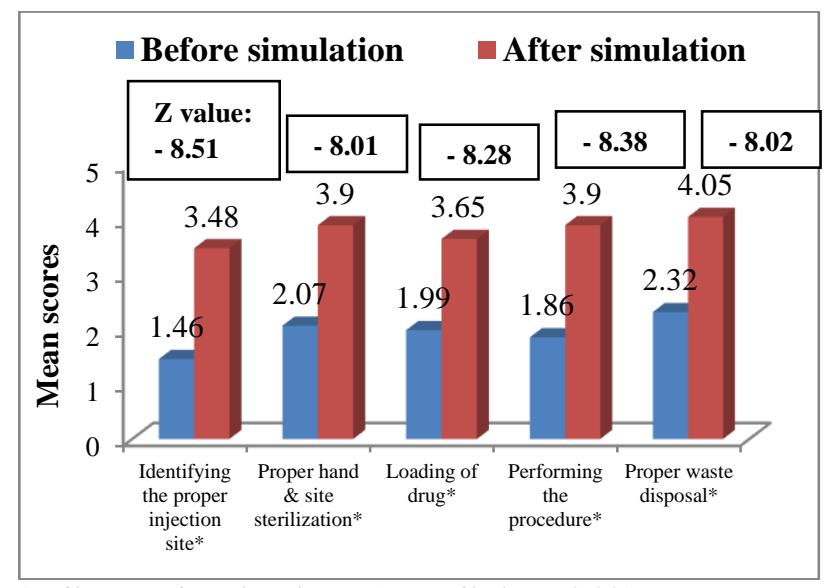

*Wilcoxon signed rank test (two-tailed): $\mathrm{p}<0.001$

\section{Figure 1: Comparison of students' confidence rating} before and after simulation.

Students' confidence ratings before and after simulation: The results were overwhelming in terms of statistically significant improvements in the confidence ratings of students $(p<0.001)$ post-simulation sessions (Figure 1).

Qualitative student responses on simulation based learning: Free-text responses from students were overall positive with students listing out their preferences for use of simulation modalities and expressing the need for such sessions in pharmacology curriculum. Students also suggested the use of high-technology and 'life-like' mannequins for a more realistic experience (Table 2).

\section{DISCUSSION}

Medical education professionals have opined that "not everything that is taught is necessarily learned; programs that best facilitate skill acquisition are those that focus on learning, rather than on teaching". 3 Simulation-based learning positions the learner at the heart of the educational process, while safeguarding patient safety. Kneebone had stressed the need for a synchrony of the learning objectives for designing simulation-based training between the learner and educator for active engagement and impactful 
learning. ${ }^{9}$ It was evident from the current study that the students' valued mannequin-based simulation as an effective means for learning procedural skills like injection techniques. These findings are in congruence with other studies conducted on mannequin-based simulation models. ${ }^{4,6,10}$ From the free-text responses, it was apparent that students understood the application of basic lifescience concepts in practical setting. This finding supports the assertion "practical is the practice of theory". 4

Table 2: Qualitative student responses on simulation based learning.

\begin{tabular}{|c|c|c|}
\hline Theme & n $(\%)$ & Responses \\
\hline \multicolumn{3}{|c|}{ The most helpful aspect of the session } \\
\hline $\begin{array}{l}\text { Better } \\
\text { understanding of } \\
\text { concepts and } \\
\text { application }\end{array}$ & $21(25 \%)$ & $\begin{array}{l}\text { "I learnt how to apply things learnt in theory in practical settings. Realized the } \\
\text { importance of surface anatomy classes" } \\
\text { "I had a better grasping about routes of drug administration" } \\
\text { "Got to know the procedure of giving injections, which is the most basic skill for any } \\
\text { doctor" }\end{array}$ \\
\hline $\begin{array}{l}\text { Reduced anxiety } \\
\text { of causing patient } \\
\text { harm and } \\
\text { improved } \\
\text { confidence }\end{array}$ & $\begin{array}{l}18 \\
(21.4 \%)\end{array}$ & $\begin{array}{l}\text { "It helped me overcome my initial fear of the procedure and identify major errors in my } \\
\text { technique" } \\
\text { "I am more confident now. It's a practice before giving it in-real, in my future clinical } \\
\text { practice" } \\
\text { "Confidence to face the patient, learnt proper method of giving injections" }\end{array}$ \\
\hline $\begin{array}{l}\text { Meaningful } \\
\text { faculty } \\
\text { interactions and } \\
\text { feedback }\end{array}$ & $\begin{array}{l}12 \\
(14.3 \%)\end{array}$ & $\begin{array}{l}\text { "Interactive sessions, teacher told me where I went wrong and I corrected my mistake } \\
\text { instantly" } \\
\text { "Attention was paid to each student at individual level" } \\
\text { "Individual attention helped me learn better, Faculty feedback helped a lot" }\end{array}$ \\
\hline $\begin{array}{l}\text { Experiential, } \\
\text { creative, fun way } \\
\text { of learning }\end{array}$ & $\begin{array}{l}14 \\
(16.6 \%)\end{array}$ & $\begin{array}{l}\text { "Creative way of learning, different from everyday lectures" } \\
\text { "Jovial way of learning things with friends" } \\
\text { "Experience, without actual consequences. There is room to make mistakes. Felt safe" } \\
\text { "Encourages learning by doing, gives chance to err and correct too" }\end{array}$ \\
\hline \multicolumn{3}{|c|}{ The least helpful aspect of session } \\
\hline $\begin{array}{l}\text { But, it's still a } \\
\text { mannequin, not } \\
\text { real. }\end{array}$ & $\begin{array}{l}46 \\
(54.8 \%)\end{array}$ & $\begin{array}{l}\text { "Mannequin wasn't life-like; It's different from that of actual human flesh. You can't } \\
\text { replace a human for a mannequin" } \\
\text { "It doesn't compensate for different body types. We can't even know if there's a } \\
\text { perforation or an emboli" } \\
\text { "It doesn't let us know the real efficiency of giving injections" } \\
\text { "The mannequins should be more realistic with dyes for arteries and sensors to } \\
\text { recognize any mistakes in procedure" }\end{array}$ \\
\hline \multicolumn{3}{|c|}{ Things you want to change about the session } \\
\hline $\begin{array}{l}\text { Improve } \\
\text { mannequin } \\
\text { quality/ High- } \\
\text { technology }\end{array}$ & $\begin{array}{l}32 \\
(38.1 \%)\end{array}$ & $\begin{array}{l}\text { "The mannequin's skin was very rough. A better quality one which resembles human } \\
\text { skin should be used" } \\
\text { "High technology mannequins with computer imaging are better" } \\
\text { "These are very basic models, gives us a piece-meal approach" }\end{array}$ \\
\hline $\begin{array}{l}\text { More time for } \\
\text { practice }\end{array}$ & $\begin{array}{l}20 \\
(23.8 \%)\end{array}$ & $\begin{array}{l}\text { "Extra sessions should be there to practice" } \\
\text { "Need more time to practice" }\end{array}$ \\
\hline More mannequins & $\begin{array}{l}18 \\
(21.4 \%)\end{array}$ & $\begin{array}{l}\text { "More number of models will allow each of us to practice for long and prevent over- } \\
\text { crowding" } \\
\text { "Increase mannequin numbers" }\end{array}$ \\
\hline \multicolumn{3}{|c|}{ Do you see the need for simulation sessions and why? } \\
\hline $\begin{array}{l}\text { Felt need for } \\
\text { simulation } \\
\text { sessions }\end{array}$ & $\begin{array}{l}41 \\
(48.8 \%)\end{array}$ & $\begin{array}{l}\text { "Yes....of course. Simulations help in learning technicalities of any topic. Please } \\
\text { include such exercises for learning emergency medicine topics like treating MI, shock, } \\
\text { stroke" } \\
\text { "Computerized simulations may be helpful in learning drug actions on human body. } \\
\text { This will get imprinted in this memory" } \\
\text { "Please include more such sessions in pharmacology. It's very much required" }\end{array}$ \\
\hline
\end{tabular}

Learning from mistakes is highly effective in acquiring factual knowledge. ${ }^{10}$ However, the fear of causing harm to the patient may impede learning, as it has been suggested that a "person's learning is profoundly affected by his or 
her thoughts and emotional responses and by having to deal with uncertainty, anxiety, overload, and stress". 9 Practising in an environment free from stress and intricacies of clinical care facilitates learning and boosts confidence. Students agreed that simulation provided opportunities for deliberate practice without putting patients at risk, an observation which has been reflected by numerous other studies. ${ }^{11-13}$

Analysis of the confidence rating questionnaires showed significant improvements in the mean confidence scores following injection training sessions; findings similar to the study conducted by Halm MD et al. ${ }^{10}$ The positive freetext responses to our intervention indicated that simulation teaching amplifies student enjoyment as well as confidence.

Purposeful practice under the direct supervision and feedback from experienced faculty is the keystone for the acquisition of expertise. Our students valued highly the role of the facilitators and their feedback in achieving effective sessions. This was supported by findings from other studies. ${ }^{4,6}$

Despite its popularity for promoting experiential learning, simulation-based technology has its own challenges namely costs related to logistics, manpower, equipment and more so realism of mannequins. ${ }^{5}$ One of the objectives of our study was to understand the students' perspectives about the challenges of using mannequins for clinical skill training. Over $50 \%$ of students felt the need for more realistic mannequins to create an authentic reproducible environment. A few more suggested for the use of technology in improving the quality. These findings are in line with a study by Gordon et al, where only $30 \%$ of students agreed for a realistic experience with simulators. ${ }^{13}$ Simulators usually range from low to high fidelity. However, according to Miller, the term 'fidelity' does not necessarily reflect the level of technology, rather entails as to "how true to life the teaching/evaluating experience must be to accomplish its objectives". ${ }^{4}$ It was also evident from the results that students not only felt the need for more time and mannequin models for practising injection skills, but also their extensive use for learning other pharmacology concepts. Given the dynamic nature of the subject of Pharmacology and its percolation into clinical years and beyond, it was heartening to see that students appreciated the role of mannequins in undergraduate medical curriculum, as an adjuvant to traditional methods, despite their shortcomings. Similar findings were reported in other studies on simulation. ${ }^{11,13}$

\section{Strengths and Limitations}

A detailed account of students' perceptions about an educational tool helps to identify and rectify the potential barriers of learning. The present study is an attempt to understand what the students think about mannequinbased training devices, by trying to explore their opinions through both quantitative and qualitative research; there by guiding us in promoting active student engagement and thoughtful curricular incorporation.

Even though there was a high student acceptance of this method for skill acquisition and an improved confidence rating post-training, one of the major limitations was that students' competence, was not objectively measured. Future research should proceed beyond the aspects of student satisfaction and be aimed at assessing educational outcomes.

\section{CONCLUSION}

The present study suggests that mannequin-based simulation exercise may be considered a valuable educational tool for learning procedural skills. The technique shows promise in undergraduate medical curriculum due to feasibility and its innate ability to boost confidence and foster critical thinking through experiential learning. Future research in this area should focus on the long-term effects on clinical competence and patient safety.

\section{ACKNOWLEDGEMENTS}

The authors extend special thanks for the essential support for this study from the students, faculty and management of BGSGIMS.

\section{Funding: No funding sources \\ Conflict of interest: None declared}

Ethical approval: The study was approved by the Institutional Ethics Committee

\section{REFERENCES}

1. Kundra S, Singh T. Feasibility and acceptability of direct observation of procedural skills to improve procedural skills. Indian Pediatr. 2014;51(1):59-60.

2. Yaeger KA, Halamek LP, Coyle M, Murphy A, Anderson J, Boyle K, et al. High-fidelity simulationbased training in neonatal nursing. Adv Neonatal Care. 2004;4:326-31.

3. Kalaniti K, Campbell DM. Simulation-based medical education: time for a pedagogical shift. Indian Pediatr. 2015;52(1):41-5.

4. Zafar M. Medical students' perceptions of the effectiveness of integrated clinical skills sessions using different simulation adjuncts. Adv Physiol Educ. 2016;40(4):514-21.

5. Doo H, Lee Y. Perception of nursing students' experience of simulation based learning: an application of Q-Methodology. International Journal of Bio-Science and Bio-Technology. 2016;8(1):31328.

6. Seropian M, Dillman D, Lasater K, Gavilanes J. Mannequin-based simulation to reinforce pharmacology concepts. Simul Healthc. 2007;2(4):218-23. 
7. Walsh CM, Garg A, Ng SL, Goyal F, Grover SC. Residents' perceptions of simulation as a clinical learning approach. Can Med Educ J. 2017;8(1):e76e87.

8. Piette A, Muchirahondo F, Mangezi W, Iversen A, Cowan F, Dube M et al. Simulation-based learning in psychiatry for undergraduates at the University of Zimbabwe medical school. BMC Medical Education. $2015 ; 15(1)$.

9. Kneebone R. Perspective: Simulation and transformational change: the paradox of expertise. Acad Med. 2009;84(7):954-7.

10. Halm BM, Lee MT, Franke AA. Improving medical student toxicology knowledge and self-confidence using mannequin simulation. Hawaii Med $J$. 2010;69(1):4-7.

11. Joseph N, Nelliyanil M, Jindal S, Utkarsha, Abraham AE, Alok Y, et al. Perception of simulation-based learning among medical students in South India. Ann Med Health Sci Res. 2015;5(4):247-52.

12. Perkins GD. Simulation in resuscitation training. Resuscitation. 2007;73:202-11.

13. Gordon JA, Wilkerson WM, Shaffer DW, Armstrong EG. Practicing medicine without risk: Students' and educators' responses to high-fidelity patient simulation. Acad Med. 2001;76:469-72.

Cite this article as: Lavanya SH, Kalpana L.

Mannequin-based simulation as an educational tool for learning injection techniques: medical students' view points. Int J Basic Clin Pharmacol 2018;7:8827. 